九州大学学術情報リポジトリ

Kyushu University Institutional Repository

\title{
Mechanical Properties and Biodegradability of Areca Nut Fiber-reinforced Polymer Blend Composites
}

Mahyudin, Alimin

Department of Physics, Andalas University

Arief, Syukri

Department of Chemistry, Andalas University

Abral, Hairul

Department of Mechanical Engineering, Andalas University

Emriadi

Department of Chemistry, Andalas University

他

https://doi.org/10.5109/4068618

出版情報：Evergreen. 7 (3)，pp.366-372，2020-09. 九州大学グリーンテクノロジー研究教育センター バージョン：

権利関係 : 


\title{
Mechanical Properties and Biodegradability of Areca Nut Fiber-reinforced Polymer Blend Composites
}

\author{
Alimin Mahyudin ${ }^{1}$, Syukri Arief ${ }^{2, *}$, Hairul Abral $^{3}$, Emriadi $^{2}$, Mulda Muldarisnur ${ }^{1}$ and \\ Mila Puteri Artika ${ }^{1}$ \\ ${ }^{1}$ Department of Physics, Andalas University, 25163 Padang, Sumatera Barat, Indonesia \\ ${ }^{2}$ Department of Chemistry, Andalas University, 25163 Padang, Sumatera Barat, Indonesia \\ ${ }^{3}$ Department of Mechanical Engineering, Andalas University, 25163 Padang, Sumatera Barat, Indonesia
}

*Author to whom correspondence should be addressed:

E-mail: syukriarief@sci.unand.ac.id; Tel :+62-812-6628-809

(Received May 4, 2020; Revised August 17, 2020; accepted September 5, 2020).

\begin{abstract}
The effect of areca fiber percentage on mechanical properties and biodegradability of polypropylene composites made with the addition of banana and taro starches has been investigated. The composites were prepared using a hand lay-up method with the fiber percentage of 3\%, 5\%, $7 \%$, and $9 \%$. The highest strength, strain, and modulus of elasticity were obtained for composites made of 3\% fiber, while the highest impact strength was obtained for the composite with $7 \%$ fiber. The biodegradability of the composites is moderate $(0.00376 \% /$ day $)$. The tensile strength, modulus of elasticity, and impact strength of the composites meet the ABS high impact standard.
\end{abstract}

Keywords: Areca fiber, polypropylene, starch, tensile strength, Impact strength, biodegradation

\section{Introduction}

Areca nut (Areca catechu) is a palm that spread in Sumatera, Borneo, Celebes, and Nusa Tenggara ${ }^{1,2}$. These plants grow naturally, even if planted they are used only as a farm separator. Areca nut plant does not receive much attention likely due to their limited use, seeds are only eaten with betel and mayang during traditional ceremonies. Eating areca nut seed is a hereditary habit in some areas in Indonesia as it is believed good for health and stamina ${ }^{3,4)}$. Areca nut is a commodity that is mostly exported to India where West Sumatera contributes approximately $30 \%$ of Indonesia areca nut export.

Areca nuts are exported while their fruit skins are removed as pulp. Areca nut skin contains fibers that can be used to replace synthetic fibers as filler in composites. Fiber occupies approximately $30-45 \%$ of the total fruit volume. Areca nut skin fibers are preferable because they are renewable, lightweight, good thermal insulator, and stronger than glass ${ }^{5}$.

Intrinsic properties of fibers like strength, density, aspect ratio, and cellulose content determine the quality of the resulting composites ${ }^{5}$. Areca nut has a high tensile strength (231.66 MPa), low density $\left(0.78 \mathrm{~g} / \mathrm{cm}^{3}\right)$, and high cellulose content $(57.35 \%)^{6}$. The greater the ratio between length and diameter of fiber (aspect ratio), the better the fiber to be used as the filler. The diameter of the areca fiber is approximately $0.4349 \mathrm{~mm}^{6}$.
Properties of composite not only depend on materials but also the interactions or bonding between fiber and matrix. Areca nut contains lignin that has a slippery surface, therefore good binding with the matrix can only be obtained after removing the lignin layer. Lignin can only be dissolved in hot alkalis ${ }^{7}$. Prior to mixing of areca fiber with matrix it is necessary to treat it with $5 \%$ alkali (e.g. $\mathrm{NaOH}$ ) at a temperature of $70^{\circ} \mathrm{C}^{8,9)}$. Another factor influencing the properties of composites is volume fraction of fiber ${ }^{10)}$. Mechanical strength of composites made of areca nut fiber and epoxy matrix with different volume percentage has been investigated ${ }^{11)}$. The highest average tensile strength $\left(5.614 \mathrm{~kg} / \mathrm{mm}^{2}\right.$ or $\left.40.705 \mathrm{MPa}\right)$ was obtained for the composite with $3 \%$ fiber, while the lowest tensile strength $\left(3.636 \mathrm{~kg} / \mathrm{mm}^{2}\right)$ was obtained for the composite with $7 \%$ fiber. The largest average strain (2.48\%) was obtained for $3 \%$ fiber volume, while the lowest strain (2\%) was for $7 \%$ fiber volume. The highest (18.2 MPa) and the lowest (14.5 MPa) average modulus of elasticity were obtained at $7 \%$ and $9 \%$ fiber volume, respectively. The binding age between fiber and matrix must also be considered to achieve strong bond between fiber and matrix ${ }^{12)}$.

In this paper we report the characteristics of composites made of areca nut fiber and polymer blend (a mixture of polypropylene with natural polymer) matrix that was treated with alkali $(\mathrm{NaOH})^{13,14)}$. The volume percentage of areca nut fiber in the polymer blend matrix was varied to obtain the best mechanical properties and 
biodegradability ${ }^{15,16)}$. The measured characteristics of the resulting composites include tensile strength, strain, modulus of elasticity, impact strength, and degradability. We found that the highest strength, strain, and modulus of elasticity were obtained for composites made of 3\% fiber, while the highest impact strength was obtained for the composite with $7 \%$ fiber.

\section{Sample Preparation and Characterization}

Experimental procedure for sample preparation and characterization procedure follow the flowchart shown in Figure 1 and described in details in the following subsections.

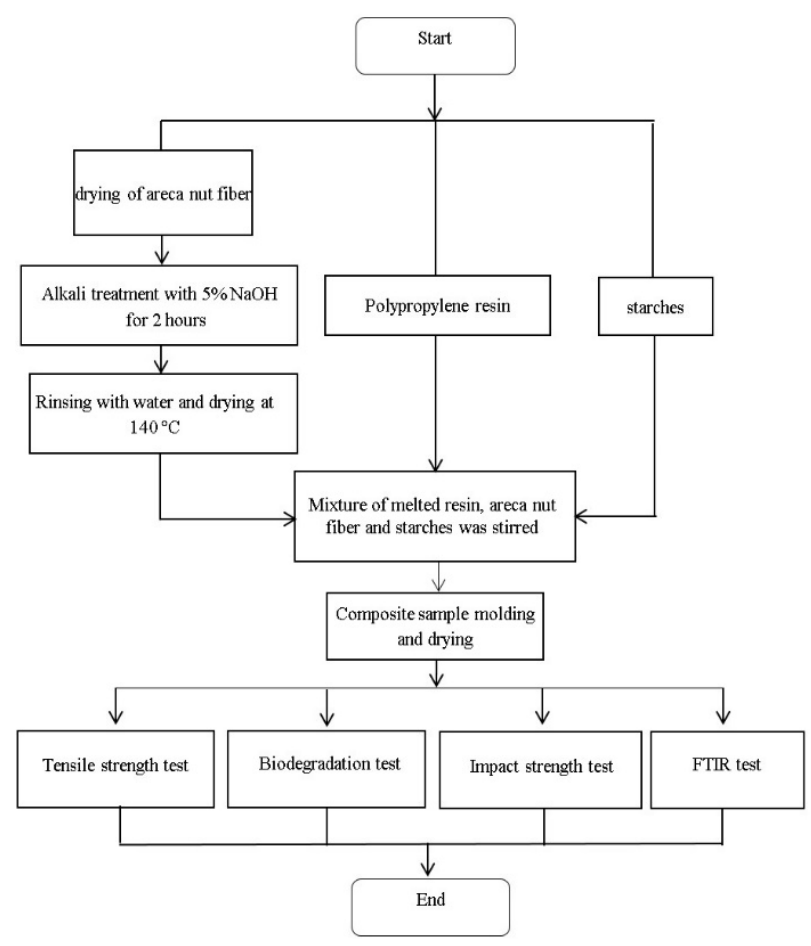

Figure 1: Flow-chart of sample preparation and characterization

\subsection{Sample Preparation}

Composite samples were prepared using the blend and hand lay-up method. Areca nuts were dried under direct sunlight for 2 days. After drying, areca fibers were separated and then soaked in a $5 \% \mathrm{NaOH}$ solution for 2 hours. After soaking, areca fibers were rinsed with water several times to remove the remaining $\mathrm{NaOH}$. The remaining water in areca fibers was removed by drying in an oven at a temperature of $140^{\circ} \mathrm{C}$ for 2 hours. Dry fibers were then cut so that their length becomes $3.5 \mathrm{~mm}$.

Polypropylene resin was melted using a hot plate at a temperature of $300{ }^{\circ} \mathrm{C}$ for 30 minutes ${ }^{17}$. The mixture of melted resin, banana (or taro) starch and fiber was then homogenized by vigorous stirring. Resin mixture was poured into a mold whose dimension $16.5 \mathrm{~cm} \times 2 \mathrm{~cm} \times 0.5$ $\mathrm{cm}$ for tensile strength test, a mold of $5 \mathrm{~cm} \times 5 \mathrm{~cm} \times 0.5$ $\mathrm{cm}$ for biodegradation test, and a mold of $5.5 \mathrm{~cm} \mathrm{x} 1 \mathrm{~cm} \mathrm{x}$ 1cm for Fourier-transform Infra-red (FTIR) spectroscopy, scanning electron microscope (SEM), and impact test. Air bubbles formed in the mold were removed using a spatula tip. The surface of the resin mixture in the mold was flattened by putting an iron bar on top of the mold that was being heated using hot plate ${ }^{18)}$. The resulting Areca nut fiber-reinforced polymer blend composites were dried for 5 minutes at room temperature. After drying, the resulting composites were removed from the molds.

Morphology of the resulting composite surface was investigated using JSM-6360LA Scanning Electron Microscope, while bonding between matrix and filler of aged samples was measured using the Perkin Elmer Frontier FTIR spectrometer.

\subsection{Mechanical Test}

Tensile strength measurement was carried out to determine the strength of the material against the tensile force. The tensile strength can be written mathematically as follows:

$$
\sigma=\frac{F}{A}
$$

where $\sigma$ is the tensile strength $\left(\mathrm{kg} / \mathrm{cm}^{2}\right), F$ is the tensile force $(\mathrm{N})$, and $A$ is the area of the sample $\left(\mathrm{cm}^{2}\right)$.

Strain is defined as a change in the size of an object due to the force in equilibrium compared to the original size. Strain in the composite was calculated using the following equation:

$$
\varepsilon=\frac{\Delta l}{l}
$$

where $\varepsilon$ is the strain, $\Delta l$ is the change in specimen length $(\mathrm{cm})$, and $l$ is the initial length of sample $(\mathrm{cm})$.

Modulus of elasticity $(E)$ is the ratio between stress $(\sigma)$ and strain $(\varepsilon)$. The modulus of elasticity is defined as:

$$
E=\frac{\sigma}{\varepsilon}
$$

\subsection{Impact Strength}

Impact test was carried out to find out how much the strength of the material. Impact strength of polymer blend composites was tested using ASTM D256-02 standard with the Izod method using Electronic Impact Testing Machine XD-5D. The impact strength was calculated using the following equation:

$$
I=\frac{E}{A}
$$

where $I$ is the impact strength $\left(\mathrm{J} / \mathrm{mm}^{2}\right), E$ is the impact absorption energy $(\mathrm{J})$, and $A$ is the cross-section area of the sample $\left(\mathrm{mm}^{2}\right)$. 


\subsection{Biodegradability test}

The simplest quantitative method for testing the biodegradation of a polymer is to determine the mass loss of material ${ }^{19)}$. The percentage of mass loss $(M L)$ can be calculated using the following relation:

$$
M L=\frac{m_{i}-m_{f}}{m_{i}} 100 \%
$$

where $m_{i}$ and $m_{f}$ are the mass of the specimen before and after the biodegradation process (g), respectively.

Degradability of a material can be determined from the rate of degraded mass at a certain time duration $(\Delta t)$. Mathematically, degradability can be calculated using the following equation:

$$
\text { degradability }=\frac{M L}{\Delta t}
$$

\section{Results and Discussion}

\subsection{Tensile Strength}

Tensile strength of the composite samples made of polypropylene resin with different areca nut fiber percentage is shown in Figure 2.

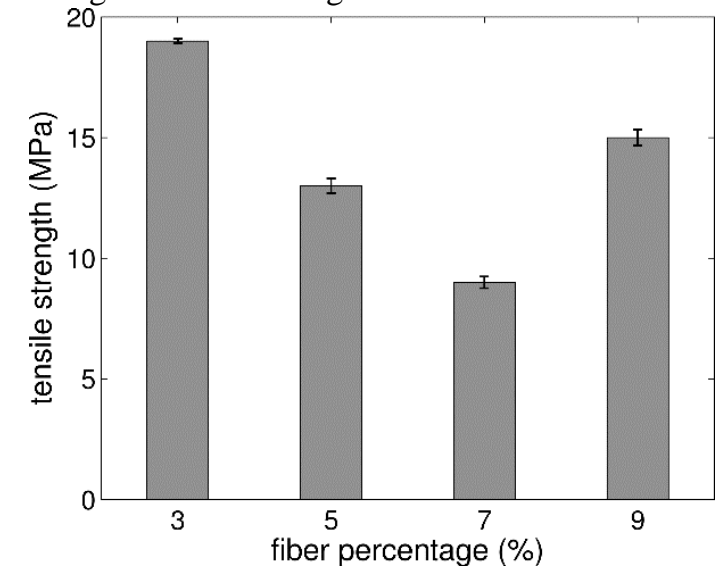

Figure 2: Effect of areca nut fiber percentage on tensile strength of the composites made of polypropylene resin, areca fiber and banana starch.

The tensile strength of the polypropylene resin mixed with banana starch decreases non-monotonously with fiber percentage. It decreases up to $7 \%$ fiber percentage and then reincreases. The highest tensile strength of 11 $\mathrm{MPa}$ is obtained for the composite with 3\% fiber. The decrease of tensile strength is due to weak bond between the fibers in the composite. The bonding becomes weaker when the fiber volume fraction increases. Percentage of fiber higher than $7 \%$ leads to irregular fiber orientation so that tensile strength of the composites decreases ${ }^{20,21)}$. Reincrease of tensile strength for fiber percentage above $7 \%$ indicates that the tensile strength of composites is influenced by the fiber volume fraction and fiber orientation. The mechanical strength of the composite increases again when the critical fiber volume percentage is achieved ${ }^{22,23)}$. Therefore, we may conclude that the critical volume fraction of the resulting composites is around $7 \%$.

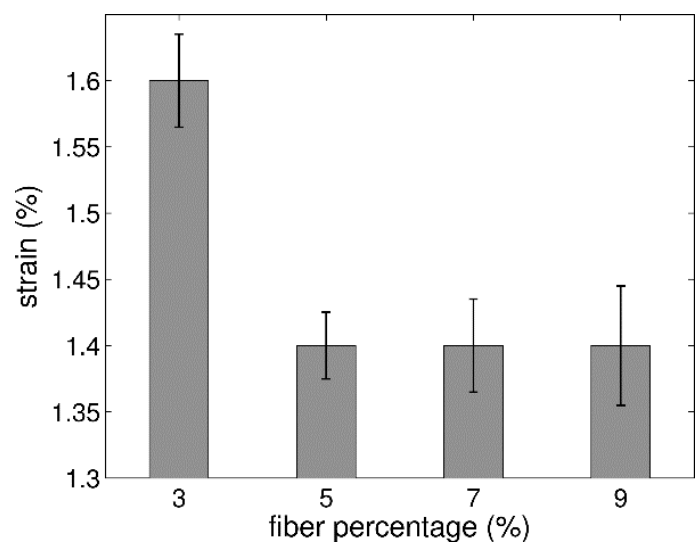

Figure 3: Effect of fiber percentage on the strain of composites made of polypropylene resin, areca fiber and banana starch.

The strain was calculated by comparing the increase of the sample length under the influence of external force with respect to its initial value. Calculated strain is displayed in Figure 3. The highest strain of $1.6 \%$ is obtained for the composite made of $3 \%$ fiber. The strain decreases when fiber percentage above $3 \%$. There is no significant change of the strain for fiber percentage between $5 \%$ and $9 \%$. Constant length increment for composites made of fiber with volume percentage above $3 \%$ indicates that the bonding of functional group between matrix and filler is quite strong, therefore the mechanical properties of the composites remain constant ${ }^{24)}$.

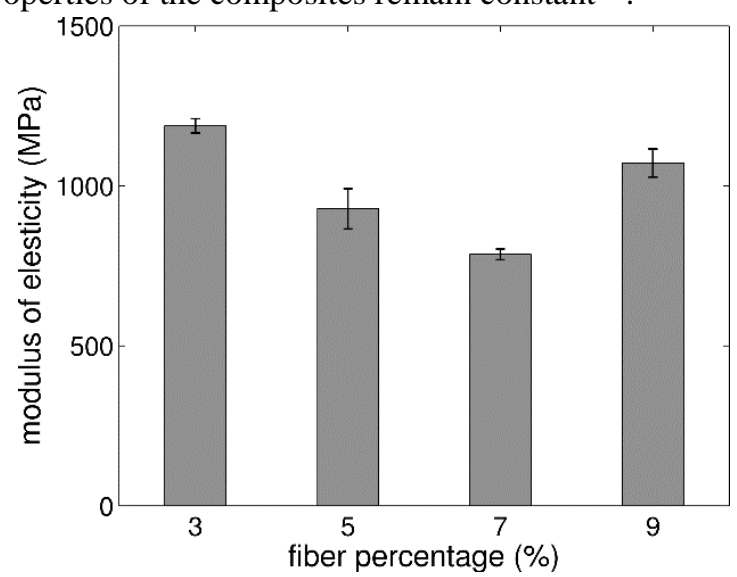

Figure 4: Effect of fiber percentage on the modulus of elasticity of composites made of polypropylene resin, areca fiber and banana starch.

Figure 4 shows the modulus of elasticity of the samples. The highest modulus of elasticity of $1187.5 \mathrm{MPa}$ is obtained for samples with 3\% fiber, while the lowest modulus of elasticity is $785.7 \mathrm{MPa}$ that is obtained for sample with $7 \%$ fiber. Modulus of elasticity decreases with the increase of fiber content. These results show that the composite has the ability to influence the stress value where the greater the modulus of elasticity, the greater the stress. 


\subsection{Impact Strength}

The impact strength test was carried out to determine the amount of energy absorbed to break the samples. The impact strength of the samples is shown in Figure 5.

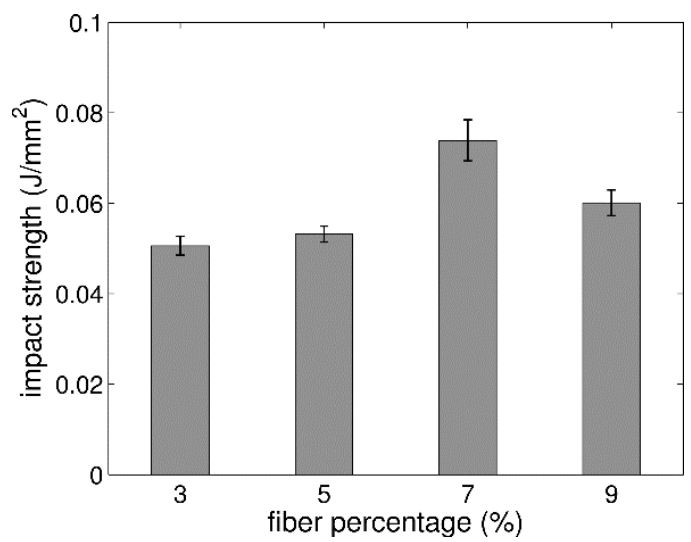

Figure 5: Effect of percentage of fiber on the impact strength of polypropylene resin mixed with banana starch

The composite with $7 \%$ fiber has the highest impact strength that is $0.0739 \mathrm{~J} / \mathrm{mm}^{2}$, while the lowest value of $0.0532 \mathrm{~J} / \mathrm{mm}^{2}$ is obtained for the sample made of $5 \%$ fiber. The difference in impact strength for sample made of different fiber percentage can be explained as a result of several factors including non-homogeneous fiber distribution. Non-homogeneous distribution causes a lowering in the ability of the composite to absorb external forces. The addition of starch to this composite causes a better impact strength because the starch mixed in polypropylene resin spreads evenly. Starch distributed homogeneously in the composite improve the ability of the composite to absorb external forces.

\subsection{Effect of sample age and starch material on impact strength}

The age of the sample influences the impact strength produced. Impact strength of samples measured after 12 days and 18 days is shown in Figure 6.

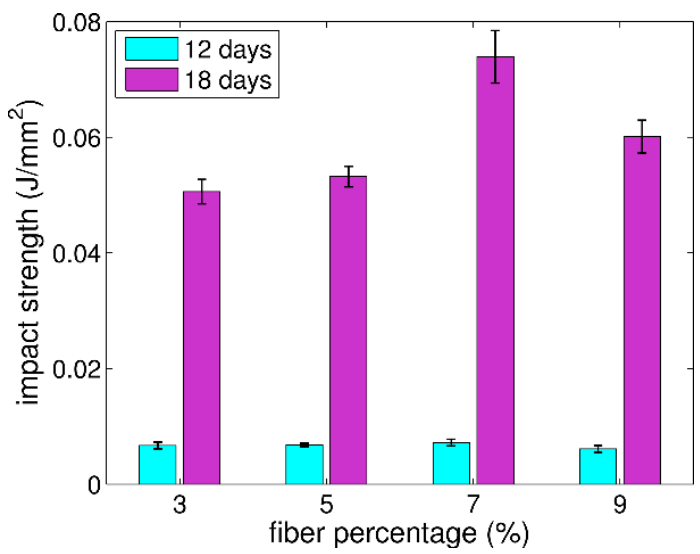

Figure 6: Effect of fiber percentage on impact strength for two different sample age (12 days and 18 days)
Samples tested after 12 days have an impact strength between $0.0061 \mathrm{~J} / \mathrm{mm}^{2}$ and $0.0072 \mathrm{~J} / \mathrm{mm}^{2}$. The impact strength increases significantly (i.e approximately one order of magnitude) when samples were measured after 18 days. This result indicates that aging leads to strengthening the bonds between matrix and filler.

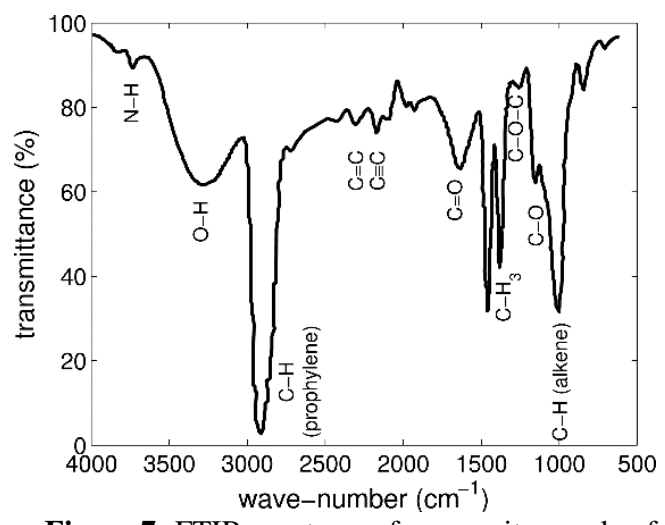

Figure 7: FTIR spectrum of composites made of polypropylene resin, areca fiber and banana starch.

FTIR spectrum (Figure 7) shows the existence of a bond between matrix and filler. Strong bond results in the increase of the mechanical strength of the composite, especially the impact strength. The polypropylene bonds are $\mathrm{C}-\mathrm{H}$ at wave-number of $2951.63 \mathrm{~cm}^{-1}, \mathrm{CH}_{3}$ at 1376.28 $\mathrm{cm}^{-1}$ and $\mathrm{CH}$ alkene at $997.62 \mathrm{~cm}^{-1}$ and the bond at banana starch is $\mathrm{OH}, \mathrm{C}=\mathrm{O}, \mathrm{C}-\mathrm{O}-\mathrm{C}^{25,26)}$. The FTIR spectrum also shows the existence of new bonds namely $\mathrm{NH}$ at wavenumber $3744.42 \mathrm{~cm}^{-1}, \mathrm{C}=\mathrm{C}$ at $2305.81 \mathrm{~cm}^{-1}, \mathrm{C}=\mathrm{N}$ at $2305.81 \mathrm{~cm}^{-1}, \mathrm{C} \equiv \mathrm{C}$ at $2167.44 \mathrm{~cm}^{-1}$ and $\mathrm{CO}$ at 1150.42 $\mathrm{cm}^{-1}$.

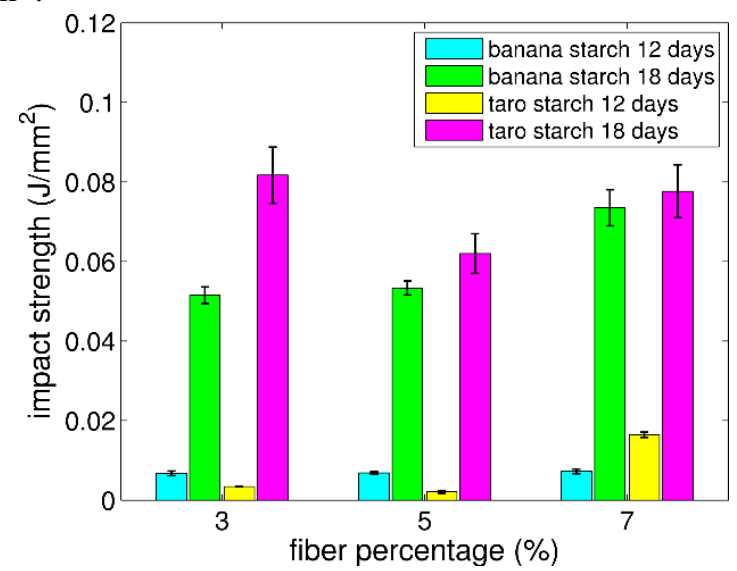

Figure 8: Effect of composite age and type of starch on impact strength of the composite

Figure 8 shows a comparison between two composites with different starches, namely taro and banana starch. The age of the composite influences the impact strength of the composite made of both starches. The material of starch determines the impact strength of the resulting composite. The composites made of taro starch has a higher impact strength. Effect of sample age is similar for banana and taro starch, 18 days aging increases impact 
strength significantly in comparison to those of samples aged 12 days.

\subsection{Biodegradability}

Biodegradation was determined based on the rate of sample mass change after burial in the soil for a specific time duration. The degradation process was determined from the mass change before and after burial. Figure 9 shows the degradation of the samples after 30-days burial.

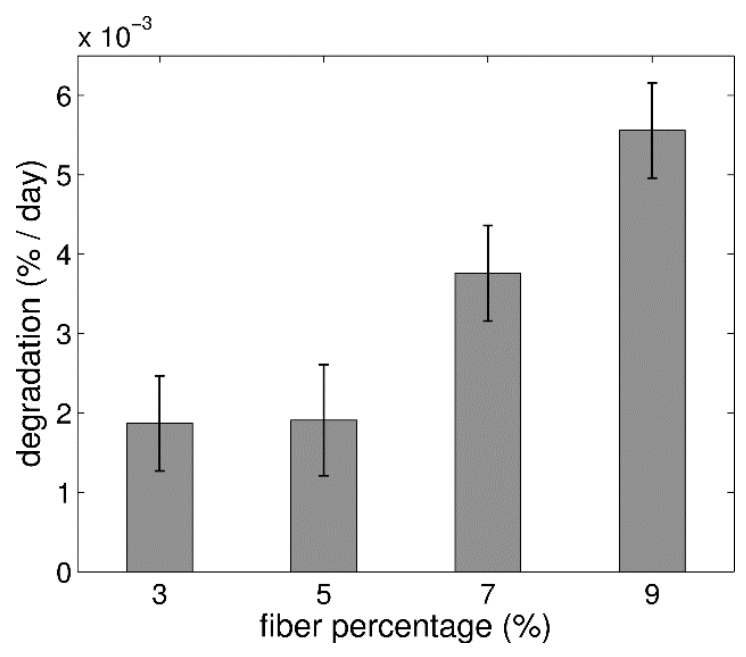

Figure 9: Effect of percentage of fiber on the rate of degradation of polypropylene resins mixed with banana starch

Degradation of composites increases monotonously within the experimental range with the increase of fiber percentage. The higher the fiber percentage, the faster the degradation process occurs. The Fastening of the degradation process is due to the fact that areca fiber is more favorable to microbes compared to the polymer. Banana starch mixed with polypropylene resin also favorable to microbes, therefore causes faster degradation process. Another very influential factor on degradation is the moisture and the number of decomposing microbes in the soill'27,

\subsection{Sample Morphology}

SEM image shows that there are many voids or cavities in the sample. The voids affect the mechanical properties of materials as it inhibit the formation of bonds between matrix and polymer ${ }^{29)}$. The mechanical properties of composites decreased with the increasing number of voids ${ }^{30}$. Figure 10 shows the SEM image of the composite sample.

The hand lay-up method has the advantage that the strength and thickness of the composite can be controlled by increasing the thickness of the fibers and resins. This method is very simple, but often causes the formation of voids in the composites ${ }^{31,32)}$. Voids reduce density and therefore the mechanical strength of the resulting composites.

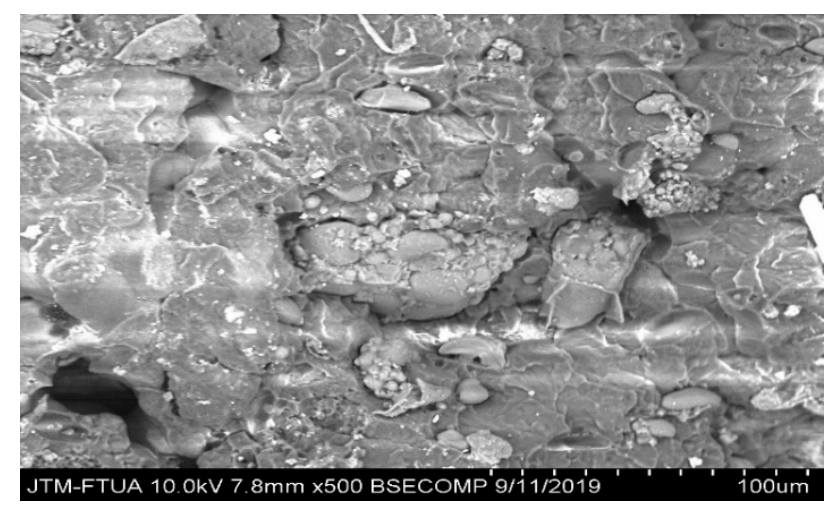

Figure 10: SEM image of composites made of polypropylene resin, areca fiber and banana starch.

\section{Conclusions}

Percentage of fiber affects the mechanical properties and biodegradability of the fiber-reinforced polymer composite. The highest tensile strength, modulus of elasticity, and strain are obtained for samples with 3\% fiber, while the highest impact strength is obtained for samples with $7 \%$ fiber. The strain value almost meets the requirement of ABS (Acrylonitrile Butadiene Styrene) high impact standard for car dashboards which is $2 \%$. The modulus of elasticity at the percentage of fiber 3\% and 9\% meet the ABS high impact standard for car dashboards that is 1000-2500 MPa. The impact strength also satisfies the ABS high impact standard for car dashboards that is $13.48 \mathrm{~kJ} / \mathrm{m}^{2}$. The age of the sample affects the composite impact strength. The Impact strength of samples aged 18 days is ten times higher than those aged 12 days. FTIR spectrum indicates the formation of new bonds namely $\mathrm{N}$ $\mathrm{H}, \mathrm{C}=\mathrm{C}, \mathrm{C} \equiv \mathrm{C}, \mathrm{C}-\mathrm{N}$, and $\mathrm{C}-\mathrm{O}$. The degradation rate of the composites is $0.00376 \% /$ day and increases with fiber percentage. SEM image indicates the presence of voids or cavities in the composite. The voids affect the mechanical properties of composites. The optimum percentage of fiber cannot be obtained because the required strengths occur at different fiber percentage. The critical volume fraction value was at a percentage of $7 \%$.

\section{Acknowledgement}

Authors would like to thank Faculty of Mathematics and Natural Sciences Universitas Andalas for research funding.

\section{References}

1) C. Prayogo, R.R. Sari, D.H. Asmara, S. Rahayu, and K. Hairiah, "Allometric equation for pinang (areca catechu) biomass and c stocks," Agrivita J. Agric. $\begin{array}{llll}\text { Sci., } & 40 & \text { (3) } & 381-389\end{array}$ doi:10.17503/agrivita.v40i3.1124.

2) R. Putriningrum, A. Nurhidayati, T. Umarianti, K.D. Listyaningsih, and W.R. Agustin, "The synergistic effects of areca nut extract and chitosan toward 
candida albicans in vitro," Int. J. Pharma Med. Biol. $\begin{array}{llll}\text { Sci., } & 5 & \text { (2) } & 142-145\end{array}$ doi:10.18178/ijpmbs.5.2.142-145.

3) R. Berlina, "Potential applications of areca nut as food (in indonesian),” Bul. Palma, 33 96-105 (2007). doi:10.21082/bp.v0n33.2007.96-105.

4) K.P. Lee, G.W. Sudjarwo, J.-S. Kim, S. Dirgantara, W.J. Maeng, and Heeok Hong, "The antiinflammatory effect of indonesian areca catechu leaf extract in vitro and in vivo," Nutr. Res. Pract., 8 (3) 267-271 (2014).

5) D.S. Bavan, and G.C.M. Kumar, "Potential use of natural fiber composite materials in india,” J. Reinf. Plast. Compos., 29 (24) 3600-3613 (2010). doi:10.1177/0731684410381151.

6) J.S. Binoj, R. EdwinRaj, V.S. Sreenivasan, and G.R. Thusnavis, "Morphological, physical, mechanical, chemical and thermal characterization of sustainable indian areca fruit husk fibers (areca catechu 1.) as potential alternate for hazardous synthetic fibers," $J$. Bionic Eng., 13 (1) 156-165 (2016). doi:10.1016/S1672-6529(14)60170-0.

7) A. Bismarck, S. Mishra, and T. Lampke, "Plant fibers as reinforcement for green composites," in: A.K. Mohanty, M. Misra, L. Drzal (Eds.), Nat. Fibers Biopolym. Biocomposites, CRC Press, Boca Raton, Florida, 2005: pp. 53-60. doi:10.1201/9780203508206.ch2.

8) S.A. Khan, S.B. Khan, L.U. Khan, A. Farooq, A. Akhtar, and A.M. Asiri, "Handbook of Materials Characterization,” Springer International Publishing, 2018.

9) C.P.K. Kencanawati, I.K.G. Sugita, N.P.G. Suardana, and I.W.B. Suyasa, "Effect of alkali treatment on physical and mechanical properties of areca nut fiber (in indonesian)," J. Energi Dan Manufaktur, 11 (1) 6-10 (2018). doi:10.24843/JEM.2018.v11.i01.p02.

10) A.K. Mohanty, M. Misra, and G. Hinrichsen, "Biofibres, biodegradable polymers and biocomposites: an overview,” Macromol Mater Eng, 276/277 1-24 (2000).

11) J.R.F.D. Kamagi, "Properties of Areca Nut Fiberreinforced Composites of Varying volume fraction of 3\%, 5\%, 7\%, and 9\% (in Indonesian)," Universitas Sanata Dharma, 2017.

12) S.P. Dwivedi, M. Maurya, N.K. Maurya, A.K. Srivastava, S. Sharma, and A. Saxena, "Utilization of groundnut shell as reinforced in development of aluminum based composite to reduce environment pollution : a review," 7 (1) 1-5 (2020).

13) R. Boujmal, H. Essabir, S. Nekhlaoui, M.O. Bensalah, R. Bouhfid, and A. Qaiss, "Composite from polypropylene and henna fiber: structural, mechanical and thermal properties, journal," Biobased Mater. Bioenergy, 8 (2) 246-252 (2014). doi:10.1166/jbmb.2014.1420.

14) P. Zhang, R.L. Whistler, J.N. BeMiller, and B.
R.Hamaker, "Banana starch: production, physicochemical properties, and digestibility-a review," Carbohydr. Polym., 59 (4) 443-458 (2005). doi:10.1016/j.carbpol.2004.10.014.

15) A. Mustea, and D.L. Manea, "Nfluence of polypropylene fibers upon the mechanical characteristics of reinforce composite mortars," Procedia Eng., $181 \quad 338-345 \quad$ (2017). doi:10.1016/j.proeng.2017.02.398.

16) F.Z. Mechtali, H. Essabir, S. Nekhlaoui, M. OuadiBensalah, M. Jawaid, R. Bouhfid, and A. Qaiss, "Mechanical and thermal properties of polypropylene reinforced with almond shells particles: impact of chemical treatments,” J. Bionic Eng., 12 (3) 483-494 (2015). doi:10.1016/S16726529(14)60139-6.

17) Nadir Ayrilmis, A. Kaymakci, and FerhatOzdemir, "Physical, mechanical, and thermal properties of polypropylene composites filled with walnut shell flour,” J. Ind. Eng. Chem., 19 (3) 908-914 (2013). doi:10.1016/j.jiec.2012.11.006.

18) D.R. Paul, and J.W. Barlow, "Polymer blends," J. Macromol. Sci. Part C Polym. Rev., 18 (1) 109-168 (1980). doi:10.1080/00222358008080917.

19) A.S. Herrmann, J. Nickel, and U. Riedel, "Construction materials based upon biologically renewable resources-from components to finished parts,” Polym. Degrad. Stab., 59 (1-3) 251-261 (1998). doi:10.1016/S0141-3910(97)00169-9.

20) R.M. Jones, "Mechanics Of Composite Materials," 2nd ed., Taylor and Francis, New York, 1999.

21) H. Sosiati, Y.A. Shofie, and A.W. Nugroho, "Tensile properties of kenaf/e-glass reinforced hybrid polypropylene (pp) composites with different fiber loading," EVERGREEN Joint Journal of Novel Carbon Resource Science \& Green Asia Strategy, 5 (2) 1-5 (2018). doi:https://doi.org/10.5109/1936210.

22) O.F. Gibson, "Principle of Composite Materials Mechanics,” Mcgraw-Hill Inc., New York, 1994.

23) M.W. Hyer, "Stress Analysis Of Fiber-Reinforced Composite Materials,” McGraw-Hill, Illinois, 1998.

24) L.A. Bello-Pérez, E. Agama-Acevedo, L. SánchezHernández, and O. Paredes-López, "Isolation and partial characterization of banana starches,” J Agric Food Chem, $47 \quad$ (3) 854-857 (1999). doi:10.1021/jf980828t.

25) K.N. Waliszewski, M.A. Aparicio, L.A. Bello, and J.A. Monroy, "Change of banana starch by chemical and physical modification,” Carbohydr. Polym., 52

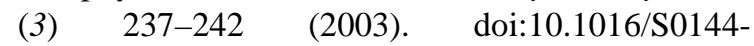
8617(02)00270-9.

26) B.C. Smith, "Fundamentals of fourier transform infrared spectroscopy,” CRC press, Boca Raton, 2011.

27) F. Firdaus, and C. Anwar, “Application of solid-fluid waste from tapioca flour industry for biodegradable plastic films (in indonesian),” Logika, 1 (2) 38 - 44 
(2004).

28) A.C. Albertsson, and S. Karlsson, "Chemistry and biochemistry of polymer biodegradation,” in: G.J.L. Griffin (Ed.), Chem. Technol. Biodegrad. Polym., Blackie Academic \& Professional, London, 1994.

29) A.R. Banagar, S.C. Venkateshappa, S.S. Kamath, and B. Bennehalli, "Tensile and flexural properties of areca sheath fibers,” Mater. Today Proceeding, 5 (14) 28080-28088

(2018). doi:10.1016/j.matpr.2018.10.049.

30) M.M. Schwartz, "Composite Materials Handbook," McGraw-Hill, 1992.

31) L. Yusriah, S.M. Sapuan, E.S. Zainudin, and M. Mariatti, "Characterization of physical, mechanical, thermal and morphological properties of agro-waste betel nut (areca catechu) husk fibre,” J. Clean. Prod., 72 174-180 (2014). doi:10.1016/j.jclepro.2014.02.025.

32) R. Khantwal, G. Gupta, and R.S. Negi, "Walnut shell reinforced composite: a review,” Int. J. Sci. Eng. Res., 7 (5) 179-189 (2016). 